\title{
The Japanese Numeral Quantifiers: An Error Analysis of Student Writings (Sakubun)
}

\author{
Gede Satya Hermawan \\ Japanese Education Department \\ Ganesha University of Education \\ Singaraja-Bali, Indonesia \\ satya.hermawan@undiksha.ac.id
}

\begin{abstract}
During language acquisition process, the learner will do try and error of the learning language. In Japanese class at the elementary level; the first-year student at first semester, they learned vocabularies, hiragana, katakana, and sentence patterns. For six months they learned and absorbed Japanese language skill; as language acquisition process. The next semester (a firstyear student at second semester), they will try to use the Japanese Language (which they are learning before) by produce the utterance, make sentences, and write a simple essay. Writing class at the elementary level in Japanese call Sakubun Shokyu. When examining the student writing, I found the interesting Japanese language usage of the numeral quantifier. By using an error analysis, the results show if the students commonly using ungrammatical pattern. The reason they did, because of Indonesian language interference, and the lack of Japanese sentence pattern at the learning process. This paper will describe the usage of Japanese numeral quantifier by the students. This research using the qualitative method. The error analysis not explained about the fallacy language usage, but this analysis will describe grammatical and ungrammatical of language usage. This analysis can become a self-evaluation, or suggestion for the lecturer to evaluate the language learning in class.
\end{abstract}

Keywords-error analysis; writing; Japanese; numeral quantifier

\section{INTRODUCTION}

The number in Japanese language, expressing by kunyomi (or Japanese pronunciation) and onyomi (or Chinese pronunciation) for reading the number of kanji. The both of pronunciation use for counting the objects. But kunyomi has limited function. Kunyomi uses for general count things, and count people just for counting one and two people, start from three people count by onyomi. Example, hitotsu (one thing), hitori (one people), sannin (three people), etc. Other, for counting objects in the Japanese language differentiated by suffix for different things. Such as, if we count the small animal, using the suffix -hiki with allomorph; -hiki, -piki, and -biki. Allomorph arises from the morphophonemic process (Tjandra, 2015).

Example: one $(\operatorname{dog})=$ ippiki [ichi+-hiki=ippiki] (no inu)

two $(\operatorname{dog})=$ nihiki $[$ ni+-hiki=nihiki $]$ (no inu)

three $(\operatorname{dog})=$ sanbiki $[$ san+-hiki=sanbiki $]$ (no inu).
The other suffix such as -nin (for count people), -dai (for count machine or thing which has a mechanical system), satsu (for count book), and others.

The student learns this concept of Japanese numeral quantifier at the elementary level. As a foreigner learner, they are trying to use the language they learned. In the middle of this process, they possible to make an error. Ungrammatical language can form. From this point, this research will describe an error analysis of Japanese numeral quantifier. Corpus collected from student writing task and analysis with a linguistic approach.

\section{ERROR ANALYSIS}

\section{A. Term of Error Analysis}

An error could happen during language acquisition or language learning process. Krasshen (1981) not distinguish between language acquisition and language learning. Language acquisition especially second language acquisition can occur in the family/social context or language context. Even though the second language learning does not become the second language in social context, this phenomenon still included in second language acquisition. For example, Indonesia mainly use Indonesian language (Bahasa), and we can say English just became official language (for education, for research, and other). English is not daily use language in Indonesia, but the student who was learning English can absorb English vocabularies, using English grammar (language acquisition) by English learning class process. The same situation happens with the Japanese language in Indonesia.

Language acquisition it becomes linguistic part and psychological (some of the view) including this part. Richard and Sampson (2014) said this approach become a comparative study, to compare two languages (first language as native language and second language as learning language -new language-). Furthermore, Richard and Sampson (2014) noted if subsequent attempts to rectify what seen as an overly theoretical approach to language learning evolve into error analysis.

The term of error it self correlated with idiosyncratic dialects. Corder (1981) disagree if we use a label as deviant, ungrammatical, or ill-formed for erroneous because that label 
means we decided the student language performance before we described. As the idiosyncratic dialects, we must treat the student erroneous as dialects which differs from the target language. But these dialects are not 'langues', because this dialect shared by people (or in this case is students) whose having a similar background.

In this paper label as ungrammatical still using for comparing between a first language and second language (target language). And ungrammatical doesn't mean it wrong, but it says it idiosyncratic.

\section{B. The Meaning of Error}

The error is not a mistake. We will discuss that difference in next chapter. Point out from Corder (1981); the error is a linguistic operation. It means, we can describe error with process interpretation of student utterance/sentence using linguistic approach. From the error, we can read the difficulties the student to produce utterance/sentence.

Corder (1981) underline about superficial of the teacher, and it makes the error analysis focus on systematic analysis, and this superficial cannot answer the question 'why the student did erroneously?', because the important thing of this kind research is giving feedback for the teacher. Furthermore, Corder gave two option method for analyzing the error. First, we can ask or give the student consultation about his/her erroneous. It calls authoritative interpretation, and for deconstructing the student erroneous, we can use authoritative reconstruction. Second, we can be interpreting the student erroneous by its form, its situational context, and it's linguistic. This method calls plausible interpretation, and for deconstructing the student erroneous, we can use plausible reconstruction.

In this research, used plausible interpretation. The context found from theme of writing task.

\section{The differences of error and Mistakes}

Brown (2007: p. 258), defined mistake refers to a performance error that is either a random guess or a 'slip' in that it is a failure to utilize a known system correctly. If we made a mistake, we could do self-corrected. For error Brown (2007: p. 259) explain if error must distinguish from a mistake, an error is idiosyncratic in the language of the learner that is a direct manifestation of a system within which learner was operating at the time. It means error reflect the competence of the learner.

It is clear the boundaries of mistake and error. A mistake can self-corrected because the person whose did mistake know the right language system. The other side, an error can not self-corrected, because the person whose did error not realized if he/she did error. As a cognitive the persons whose did error think they are doing right or proper language system.

\section{JAPANESE NUMERAL QUANTIFIER}

In general, numeral quantifier use for counting the object. Tsujimura (2007) pointed about Japanese Numeral quantifier, such as:
1. Japanese numeral quantifier can use as modifiers, placed before the noun phrase that they modify (as prenominal modifier). The genitive particle 'no' used after numeral quantifier to indicate of the modification relation. Example,

Sannin-no kodoma-ga uchi-e kita.

three-Gen child-Nom house-to came.

(Tsujimura, 2007: p. 236)

Note: ga is a nominative case particle in Japanese.

2. Japanese numeral quantifier has phenomenon call Quantifier Floating. This phenomenon can be made numeral quantifiers are separated from the noun that they modify, and doesn't make meaning change. Example,

(a) Taroo-ga sanmai-no kami-o katta. Taro-Nom three-Gen paper-Acc bought.

(b) Taroo-ga kami-o sanmai katta. Taro-Nom paper-Acc three bought.

(Tsujimura, 2007: p. 236)

Note: $\mathrm{o}$ is an accusative case particle in Japanese.

The sentence in (b) with floated quantifier which sanmai not placed before the noun but placed before the verb. This phenomenon cannot be categorized as ungrammatical. It can become ungrammatical if the numeral quantifier freely set anywhere. Tsujimura (2007), noted although numeral quantifier separated from modified, they can not be placed anywhere, because they have a structural restriction.

\section{JAPANESE NUMERAL QUANTIFIER ERROR}

After collecting 61 data, the analysis identifying two domain of error. The two error domain is confused by synonym; and case particles.

\section{A. Confused by Synonim}

The common pattern I found is using the suffix - tsu for counting things which the student doesn't know or unlearn suffix. The suffix -tsu uses for count thing as general, and can replace another suffix like:

(a) mikan-ga hitotsu orange-Nom one

(b) mikan ga ikko orange-Nom one

If we buy an orange, we can say mikan-ga hitotsu or mikan-ga ikko. The suffix - ko use for counting small things, such as egg, orange, dice, others. But as general count quantifier, the suffix -tsu cannot replace all Japanese quantifier. When we count people like futari -two person-, that's cannot substitute by futatsu -two things.

The students using the -tsu strategies when they don't know the suffix. The error I found, as below.
a1. kyoumi-no aru interest-Gen article
a2. kyoumi-no aru Interst-Gen article
kutsu-ga hitotsu arimasu. shoe-Nom one article kutsu-ga issoku arimasu. shoe-Nom one pair article
b1. Eigo-no hon-ga futatsu kaimashita. English-Gen book-Nom two buy-past


b2. Eigo-no hon-ga nisatsu kaimashita. English-Gen book-Nom two buy-past

Nominal quantifier hitotsu (a1) used by the student to count one pair of shoes. For counting shoes in Japanese use suffix soku, and for one pair shoes become issoku (a2). b1 present the error for the counting book. The student use futatsu (b1) to counting book, but Japanese numeral quantifier has the suffix -satsu (b2) for counting book.

Other, found mistake concept of numeral quantifier for counting clothes or one set clothes. The suffix -chaku use for count clothes like, jacket, cardigan, suit, one set clothes, or others, But for count shirt or t-shirt, use suffix -mai that indicate to count the thin things like paper, stamp, shirt, t-shirt, and others. The student tends to use the suffix -chaku for counting all clothes, including shirt and t-shirt. Example as below.

$$
\begin{aligned}
& \text { c1. shatsu-ga sanchaku-(o) kai-tai desu. } \\
& \text { shirt-Nom three-(Acc) buy-want to copula } \\
& \text { d1. kuroi shatsu-wa jucchaku-(ga) arimasu. } \\
& \text { black shirt-(Top) ten-(Nom) article } \\
& \text { e1. shiroi shatsu-wa jucchaku-(ga) arimasu. } \\
& \text { white shirt-(Top) ten-(Nom) article } \\
& \text { Note: wa is a topic marker. }
\end{aligned}
$$

\section{B. Case Particles}

Japanese language have five case particles; -ga (nominative), -o (accusative), -ni (dative), -no (genitive), and -wa (genitive) (Ono, 1973; Tsujimura, 2007; Tjandra, 2015). The student problem is placing numeral quantifier in sentences. As a noun, numeral quantifier use with particle -no to modification relation for the other noun, like below.

$$
\begin{aligned}
& \text { f. watashi-wa rokusoku-no kutsu-ga arimasu. } \\
& \text { I-Top six -Nom shoe-Nom have }
\end{aligned}
$$

In the f sentences -no particle establish a modification relation between nominal quantifier rokusoku to kutsu as the following nouns.

The student error can find at sentence $\mathrm{c} 1, \mathrm{~d} 1$, and $\mathrm{e} 1$. This error because the student doesn't have perfectly concept about quantifier floating. Accusative particle $-\mathrm{o}$ have a function of marking the noun as a direct object. But, $\mathrm{c} 1$ use $-\mathrm{O}$ without noun as a direct object. Numeral quantifier as a noun cannot be the direct object. The one noun can become an object in the $\mathrm{c} 1$ is shatsu. If deconstruct the $\mathrm{c} 1$ and make shatsu become a direct object, can be like below.

$$
\begin{array}{ll}
\text { c2. shatsu-o sanmai } & \text { kai-tai desu } \\
\text { shirt-Gen three } & \text { buy-want to copula }
\end{array}
$$

If a noun shatsu keep become subject of sentence, c1 can modify like c3. But, it still become ungrammatical language, because c3 has subject but doesn't have object. Modified verb kaitai (want to buy) need object to give information "what kind things do you wont to buy'.

$$
\begin{array}{llll}
\text { c3. shatsu-ga sanmai } & \text { kai-tai } \\
\text { shirt-Nom three } & \text { buy-want to copula }
\end{array}
$$

Sentence $\mathrm{d} 1$ and $\mathrm{e} 1$ have same problem, numeral quantifier treat as an object in the sentences. It is wrong because the numeral quantifier have function to explain topic ( $\mathrm{d}$ and e), and get quantifier floating become $\mathrm{d} 1$ and $\mathrm{e} 1$. For deconstruct this sentence just removing particle $-\mathrm{ga}$, and become $\mathrm{d} 2$ and e2.

d. juumai-no kuroi shatsu-wa arimasu. ten-(Gen) black shirt-(Top) article

d2. kuroi shatsu-wa juumai arimasu. black shirt-(Top) ten article

e. juumi-no shiroi shatsu-wa arimasu. ten-(Gen) white shirt-(Top) article

e2. shiroi shatsu-wa juumai arimasu. white shirt-(Top) ten article

Furthermore, the reason two domain an error happen in the Japanese class in the lack of language transfer. The process of sentences created is transferred language from Bahasa to Japanese. While transfer process, the Bahasa concept insert to Japanese language concept. This makes an error for diction or choosing a word. Other, the student doesn't have learned Japanese grammar properly, that caused unperfectly Japanese language grammar can arise..

\section{CONCLUSION}

. Using an error analysis, the results show if the students commonly using ungrammatical pattern. The result noted two domain; confused by synonym; and case particles. The reason the student did, because of Indonesian language interference, and the lack of Japanese sentence pattern during the learning process. This process happens because of language transfer from Bahasa to Japanese.

\section{References}

Brown, H. D. (2007). Principle of language learning and teaching $\left(5^{\text {th }}\right.$ Ed.). USA: Pearson Education Inc.

Corder, S. P. (1981). Error analysis and interlanguage. Oxford: Oxford University Press.

Erdogan, V. (2005). Contribution of error analysis to foreign language teaching. mersin university Journal of The Faculty of Education, 1(2), 261-270. doi: 10.17860/efd. 22900

Hasyim, S. (2002). Error analysis in the teaching of English. $K @ t a \quad J o u r n a l, \quad 4 \quad$ (1), $42-50$. https://doi.org/10.9744/kata.4.1.62-74

Khansir, A. A. (2012). Error Analysis and Second Language Acquisition. Theory and Practice in Language Studies, 2 (5), 1027-1032. doi: 10.4304/tpls.2.5.1027-1032

Ono, Hideichi. (1973). Japanese grammar. Tokyo: The Hakuseido Press.

Richard, J. C. (Eds). (2014). Error analysis: Perspectives on second language acquisition. New York: Routledge.

Tjandra, S. N. (2013). Sintaksis Jepang. Jakarta: Binus Media Publishing.

Tjandra, S. N. (2014). Morfologi Jepang. Jakarta: Binus Media Publishing.

Tsujimura, Natsuko. (2007). An introduction to Japanese language. USA: Blackwell Publishing. 